\title{
How do refugees affect social life in host communities? The case of Congolese refugees in Rwanda
}

\author{
Veronika Fajth ${ }^{1}$ Özge Bilgili ${ }^{2 *}$, Craig Loschmann ${ }^{3}$ and Melissa Siegel ${ }^{3}$
}

\author{
* Correspondence: o.bilgili@uu.nl \\ ERCOMER, Utrecht University, \\ Heidelberglaan 1, 3584 CS Utrecht, \\ the Netherlands \\ Full list of author information is \\ available at the end of the article
}

\begin{abstract}
This paper investigates how social dimensions of life in local communities are affected by the long-term presence of Congolese refugees in Rwanda, paying particular attention to feelings of safety, social networks and trust. To gauge whether increased probability of interaction with refugees reduces cohesion, these outcomes are compared across local households at varying distances from a refugee camp. This paper is based on mixed methods approach including new data originating from a household survey conducted in host communities surrounding three refugee camps, as well as information from focus group discussions. The quantitative analysis shows no statistically significant differences between host communities with the exception of informal social networks, which are higher in communities closer to refugee camps. However, qualitative evidence illustrates how greater (economic) interaction between the two populations helps increase trust between refugees and host communities over time. Moreover, locals argue that economic and social support given to refugees plays a key role in reducing and preventing conflict between the two groups. These findings map the experiences and give voice to host communities' perspectives on social life in their community.
\end{abstract}

Keywords: Forced migration, Impact of migration, Refugees, Community integrated approach, Social cohesion, Trust, Social networks, Congolese refugees, Rwanda

\section{Introduction}

Low and middle income countries host the majority of refugees worldwide, with recent estimates as high as $85 \%$ in 2017 (UNHCR, 2018a). In most of these countries hosting large numbers of refugees, local communities often experience a high level of poverty and face increased chances of economic vulnerability. In this regard, their economic conditions are not necessarily better than those seeking refuge in their communities. This situation as a result may lead to economic competition over scarce resources between host and refugee communities and cause increased social tensions within the society. Despite this evident potential threat to social cohesion, the social impact of hosting refugees on local communities has remained an understudied field of inquiry. The impact of displacement on host communities has been primarily investigated in relation to economic and environmental effects (see, e.g., Kreibaum, 2016; Maystadt \& Verwimp, 2014; Ruiz \& Vargas-Silva, 2015; Whitaker, 2002). In this paper, we argue

(c) The Author(s). 2019 Open Access This article is distributed under the terms of the Creative Commons Attribution 4.0 International License (http://creativecommons.org/licenses/by/4.0/), which permits unrestricted use, distribution, and reproduction in any medium, provided you give appropriate credit to the original author(s) and the source, provide a link to the Creative Commons license, and indicate if changes were made. 
that it is important to go beyond the analysis of economic impacts and look into how social life is affected by the presence of refugees in order to promote not only prosperous, but also cohesive, peaceful and inclusive societies.

This study helps to fill the gap in the literature by investigating how the presence of Congolese refugees affect some of the most important dimensions of social life in Rwandan host communities. Two main factors make this a particularly interesting case for the study of this topic. The first factor relates to the size and protracted nature of the displacement situation of Congolese refugees in Rwanda. Nearly half of the 170,000 refugees residing in Rwanda are from the Democratic Republic of Congo (DRC), and most have been living in their respective camps for more than two decades (UNHCR, 2018b). This long-term presence of refugees has allowed for social interaction between groups to become part of everyday life, and makes it all the more interesting to study the social dynamics within society. Second, this case is noteworthy because of the political context within which social relations take place. Namely, the Rwandan government has a relatively unrestrictive, integrative policy approach to hosting refugees which gives them increased rights of mobility, access to social services such as health and education and opportunities for economic interactions (O'Connor, 2013; UNHCR, 2011). This unique context gives us the opportunity to investigate how social life is affected in host communities that have more opportunities to interact with refugees on a daily basis. It should be noted that our case is also particular in terms of cultural proximity between hosts and refugees, as many Congolese refugees are associated with some Rwandan ancestry and more often than not speak the same language as the host population. Even though our analysis is specific to the Rwandan case, the results and discussion should be relevant to other refugee-hosting settings where displaced populations and local communities interact regularly, particularly in contexts where hosts and refugees come from similar cultural backgrounds.

Examining the effects of refugees on social dimensions of life is a challenging task due to the absence of a standard, theoretically derived conceptual definition of social cohesion (Guay, 2015). Elements commonly used to describe a cohesive society include a principle of inclusivity, cooperation, a sense of belonging, trust, and overall strong, positive relationships. Low cohesion in a society, on the other hand, is often characterised by social tension and/or fragmentation, conflict and negative feelings like resentment, anxiety, perceptions of threat among members of the community (Guay, 2015; OECD, 2011; Stanley, 2003). Given the multifaceted nature of a community's social life and considering data availability, we look at a range of selected manifestations of social cohesion: perceptions of safety within the community, presence of formal and informal social networks and trust within a host community towards different groups including the community itself, refugees, international organizations (IOs) and nongovernmental organizations (NGOs). To explore possible differences in contact between refugees and hosts, we compare these outcomes for local households within communities at varying distances from - and therefore exposure to - the three largest Congolese refugee camps, namely Gihembe, Kigeme and Kiziba. The empirical analysis relies on data from a unique household survey conducted among host communities outside of these three camps in 2016. Moreover, we make use of insights from in-depth focus group discussions (FGDs) to better understand the statistical results and bring to 
the fore the experiences and perceptions of host communities concerning their relations with refugees.

\section{Social cohesion in forced displacement contexts}

The interest to understand the impact of displaced populations on host communities has led to a growing literature in recent years. A review of this literature, however, reveals various shortcomings of the research field. First, there has been a strong thematic focus on the economic and environmental effects of refugee hosting while the social impact often remains unstudied. This is especially true for African countries and the Global South in general, compared to the European and North American contexts where social effects of immigration - even if not of refugees specifically - have been studied more extensively (e.g. Gesthuizen, van der Meer, \& Scheepers, 2009; Kesler \& Bloemraad, 2010). Second, the existing studies on the topic are small scale and mostly qualitative in nature (e.g. Porter et al., 2008; REACH, 2014; Whitaker, 1999). While this type of research has been useful in identifying the types and sources of possible social effects, there is a clear need for more studies that combine quantitative and qualitative insights based on innovative research designs to more robustly assess the ways in which the refugees' presence may influence host communities' social life. In the following, we discuss how living nearby a refugee population may affect formal and informal social networks, feelings of safety and trust among locals towards different segments of the society.

\section{Engagement with formal and informal social networks}

Social networks, both formal and informal, are cornerstones of a connected and cooperative community. For instance, engagement in formal networks (e.g. organizational membership) indicates an individual's level of civic engagement and active participation in the life of the community, while informal networks may reflect an individual's access to social support mechanisms (Gesthuizen et al., 2009). Indeed, informal networks may reflect to what extent an individual is able to count on others (beyond their household) for financial, social or emotional help in time of need.

The relationship between the presence of refugees and locals' social networks can be discussed in various ways. An often-used approach interprets the arrival of refugees as an increase in diversity within the host community. In his 'Hunkering Down' Theory, Putnam predicts an increase in diversity in a population will lead inhabitants to 'withdraw from collective life, $[\ldots]$ to withdraw even from close friends, [...] to volunteer less [...]' (Putnam, 2007, pp. 150-151). The inflow of a displaced population from a neighbouring country may also be understood as an increase in diversity. Considering Putnam's theory, this inflow could therefore lead to a decrease in social networks, both formal (for example, through community organizations and other organised collective activities) and informal (close friends). Alternatively, building upon Intergroup Contact Theory, one can also argue that diversity in terms of larger outgroup size provides opportunities for positive intergroup contact and increased contact, especially when on equal terms, can also enhance positive experiences and out-group attitudes (Allport, 1954; Pettigrew, 1998). Given the lack of empirical studies focusing on the social network effect of hosting refugees in particular, we draw conclusions based on research 
that looks at the effects of migrant stocks, which in our view is comparable considering the protracted nature of Congolese refugees in Rwanda.

With regards to organizational membership, in a cross-country study focusing on developed countries between 1981 and 2000, Kesler and Bloemraad (2010) find that on average, the relative migrant stock has a significant positive association. Similarly, using data from 28 European countries, Gesthuizen et al. (2009) examine the role of migrant stock and find a significant positive association with organizational membership in the country as well as inhabitants' propensity to give informal help. Both studies stress the key role of institutional and political contexts. In another cross-European study with a more limited topical focus, Benos and Kammas (2018) examine the effect of ethnic diversity on workers' participation in trade unions and find a significant negative association. In summary, most evidence from developed countries challenges the claim that the presence of migrants in general would weaken formal and informal social networks within the community, but the role of differing social environments is stressed.

In this research, we seek to examine the nature of these links in a low-income country context. In Indonesia, Mavridis (2015) finds a negative association both for willingness to help (a measure of informal networks) and community participation (formal networks). To the best of our knowledge, only Whitaker (1999) examines the influence of refugees on social networks in a low-income setting, in his case Tanzania. He explains that Tanzanian hosts establish extensive social relations with refugees, especially in areas close to the camps. These relations include visiting one another, attending social functions such as weddings and funerals and even competing in local sport competitions. We believe such evidence underlines the need to examine the issue in more depth and on a larger scale.

\section{Subjective safety within community}

There are a few theoretical arguments as to why hosting refugees may threaten (real or perceived) safety: firstly, refugees' prior exposure to violence may increase their likelihood to perpetrate future violence; secondly, the relative social and economic deprivation from opportunities may increase propensity to engage in criminal activity (Depetris-Chauvin \& Santos, 2018). Whitaker (1999), on the other hand, argues that host populations do not always blame refugees for changing social dynamics but see the events as an inevitable result of the drastic population increase in the area. Another, more optimistic, perspective argues that an influx of immigrants might 'revitalize' communities and spark beneficial neighbourhood social processes which will ultimately increase safety (Feldmeyer, Madero-Hernandez, Rojas-Gaona, \& Sabon, 2019).

The empirical evidence on the security effect of hosting refugees for local communities is not clear-cut. A considerable body of literature has examined the actual prevalence of security risks among refugee-hosting populations, such as a rise in criminal and violent activities (see e.g. Amuedo-Dorantes, Bansak, \& Pozo, 2018; Collier \& Hoeffler, 2004; Depetris-Chauvin \& Santos, 2018; Jacobsen, 2002; Masterson \& Yasenov, 2018; Salehyan, 2007; Schmeidl, 2002; Whitaker, 1999), but the findings of this literature remain inconclusive (sometimes even for the same country, see, e.g., UNHCR, 2003, versus Rutinwa \& Kamanga, 2003, in Tanzania).

Evidence on how the hosting community's feelings of safety are affected is more scarce: two recent studies, for instance, examine the effect of general diversity (not only 
refugee presence), with different results: positive in the case of a US study (Feldmeyer et al., 2019) and negative in the case of Indonesia (Mavridis, 2015). The lack of consistency in both types of results challenges the assumption of a negative link between hosting refugees and feelings of safety within a community and highlights the need to examine the relationship in different contexts. In this paper we focus on hosts' subjective perceptions of safety and investigate this in a low-income, conflict-neighbouring environment in which hosts and refugees, share some cultural familiarity.

\section{Trust in own community, refugees and organizations}

Putnam's (2007) 'Hunkering Down' Theory predicts community trust to be threatened by higher diversity within the community. However, the empirical evidence on this issue is almost non-existent in low-income country contexts and inconclusive for other countries. In a comparative study across European countries, Hooghe, Reeskens, Stolle, and Trappers (2008) find no clear confirmation of the hypothesised negative relationship between rising ethnic diversity and trust. In another cross-European analysis Gesthuizen et al. (2009) find different results for dynamic and static diversity measures: net migration exhibits a negative association with interpersonal trust in society, but the size of the migrant stock and the degree of ethnic fractionalization does not seem to affect trust. Ultimately, Gesthuizen and colleagues conclude that both trust and social engagement are influenced less by diversity per se and more by institutional and political contexts.

In their comparative study of developed countries, Kesler and Bloemraad (2010) find no 'general' link between change in diversity and social trust, but also point to the moderating role of the country context: in more economically equal and multicultural societies the potential negative relationship between immigration and trust is mitigated or even reversed. Laurence, Schmid, and Hewstone's (2019) UK case study finds that neighbour-trust is reduced by diversity only in cases when the out-group is viewed as threatening, a perception that is exacerbated by socio-economic precariousness. Delhey and Newton (2005) are the only ones, to our knowledge, to include less developed and African countries in their 60-country comparison. Looking at the static indicator of ethnic heterogeneity, they find a negative relationship with generalised trust in all countries, but the link is weak outside of Nordic societies. Indeed, Goldschmidt (2017) finds further evidence for the negative link in Sweden - but so does Mavridis (2015) in Indonesia.

Country context thus shapes the relationship between immigration and social cohesion; however, prior evidence from low-income, refugee-hosting contexts is scarce. Considering the factors above, the Rwandan context is mixed: inequality and socio-economic precarity are present, but the negative effects may be counteracted by the cultural proximity between hosts and refugees (potentially reducing out-group threat) and the fairly inclusive policy approach.

In addition to trust within the community, in this paper we also examine the host communities' trust in refugees as well as in IOs and NGOs providing support for the refugee population. Negative attitudes towards refugees, thereby weaker trust, can stem from multiple sources such as real or perceived competition over jobs, public goods and scarce resources, as well as differences in values and conventions (Christophersen, 
Liu, Thorleifsson, \& Tiltnes, 2013; Harb \& Saab, 2014; Mercy Corps, 2013; Porter et al., 2008; REACH, 2014; World Bank, 2013). Trust in refugees can also depend on the quality of interactions: in a cross-European study, Laurence and Bentley (2018) find a positive net effect of rising diversity on attitudes towards immigrants that is mediated by (positive) interethnic contact (while instances of negative contact, although rarer, increase negative attitudes). Locals' trust and general attitudes towards IOs and NGOs can be influenced by the perceived (un)fairness of the aid and support provided to refugee populations, which is often seen as neglecting the local poor (Christophersen et al., 2013; REACH, 2014; World Bank, 2013). To our knowledge, no research to date has explored the feelings of trust of the host community with regards to these segments of the society, which we believe is of great importance. Firstly, because there is very little evidence on this issue in a time where the media and public debate portrays the presence of refugees as a predominantly a negative matter for local communities. And secondly, because giving voice to locals' feelings and perceptions can help develop solutions that are beneficial for all members of the society and prevent feelings of distrust, anxiety and resentment.

In short, even though there exist theoretical arguments pointing to a potentially negative relationship between the influx of a large refugee population and local social cohesion, there also exist considerable evidence that goes in the opposite direction portraying positive social impacts. What is more, it is clear these effects are context-specific and highly conditional on local policies towards refugees as well as cultural (dis) similarities. In this paper we take into account formal and informal networks within community, feelings of safety and trust towards refugees, IOs and NGOs as central components of a cohesive, inclusive and peaceful refugee hosting community (Fig. 1). These perception-based indicators may not be sufficient for assessing the objective state of social life in a refugee hosting society, however we believe they are essential in bringing to the fore subjective perspectives regarding how locals experience living close to refugees. In the following section, we zoom into the specific situation of Rwanda and their history of hosting Congolese refugees to contextualise the current study.

\section{Congolese refugees in Rwanda}

Conflict and political instability have been notoriously widespread across the Central Africa and Great Lakes sub region in past decades. Most recently, recurring security

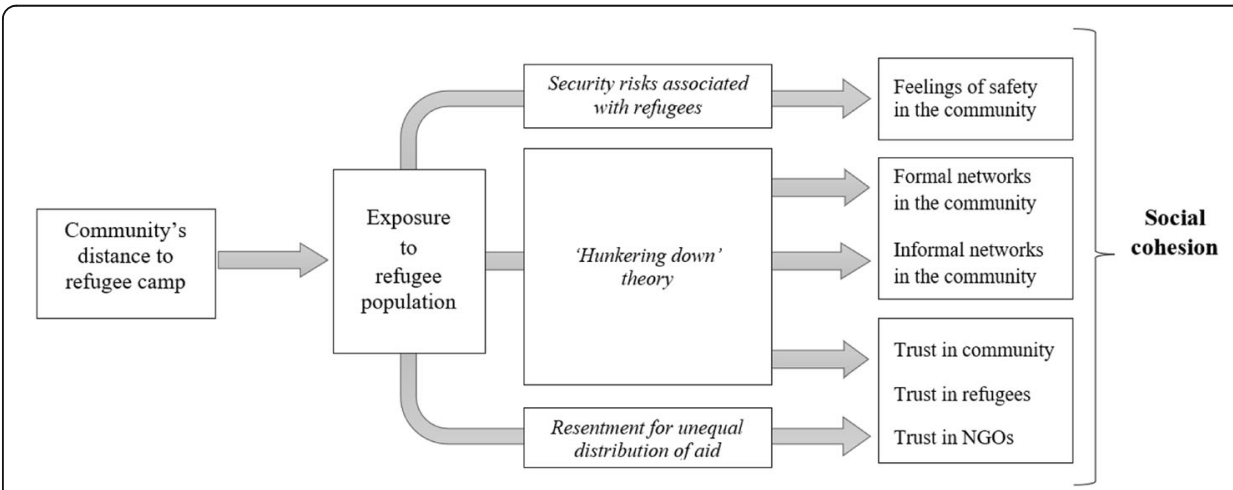

Fig. 1 Conceptual framework: links between proximity to refugee camps and social cohesion in local communities. Legend: none 
problems in the DRC and Burundi have caused relatively considerable displaced populations to seek refuge in Rwanda and other neighbouring countries. Despite having experienced massive forced displacement itself during the conflicts of the early 1990s, the Rwandan population has been hosting refugees - primarily from the DRC, but also other neighbouring countries - for decades. By the end of 2017, over 170,000 refugees were hosted by Rwanda including more than 80,000 from the DRC (UNHCR, 2018b).

Congolese refugees hosted in Rwanda generally originate from the North Kivu area of the DRC and are mostly of Banyarwanda background, which refers to Rwandan ancestry (UNHCR, 2014). North Kivu borders Rwanda and has received waves of Rwandan immigrants throughout the twentieth century. Although hardly a homogenous or united entity, the Banyarwanda have historically been the largest ethnic group in North Kivu and Kinyarwanda, an official language of Rwanda, is widely spoken in the area (Stearns, 2012). The Banyarwanda - and its subgroups have been key actors in the violent political power struggles of the DRC in past decades and have repeatedly fled from violence and persecution to Rwanda (ibid., UNHCR, 2014). While a majority of Congolese refugees have some Rwandan origins, the precise extent and meaning of this heritage are unclear. ${ }^{1}$ In conclusion, while its implications should not be overstated, the potential socio-cultural familiarity between refugees and hosts is an important factor to be taken into consideration while interpreting the findings.

Approximately $90 \%$ of Congolese refugees in Rwanda reside in one of the five camps spread throughout the country: Gihembe and Nyabiheke camps in the North, Kiziba camp near the western border, and Kigeme and Mugombwa camps in the southern part of the country. Four of these camps host 'old caseload' refugees, referring to refugees who entered the country during the first or the second Congo wars that respectively took place between 1996 and 1997, and between 1998 and 2003. Due to a new outbreak of violent conflict in Eastern DRC, Kigeme camp was opened in 2012 to accommodate an inflow of nearly 30,000 new Congolese refugees.

The Rwandan government has adopted a relatively permissive policy for refugees, allowing for the freedom of movement and work. Moreover, the government has promoted a community-integrated approach to social services, meaning that where possible refugees and local Rwandans have access to the same public services (e.g. health and education services) and the labour market. The Rwandan government also makes land available for refugee camps. This approach in essence allows refugees to be present in local communities even though they still predominately reside in the camps, and provides opportunities for social and economic interaction with host populations. Furthermore, Congolese refugees have the right to apply for Rwandan citizenship, which can facilitate refugees' integration into their host communities.

This approach has been under development since October 2009, when UNHCR proposed a comprehensive strategy to bring to a closure the Rwandan refugee situation following the post-war period (UNHCR, 2011). It can be considered as part of the broader reintegration assistance provided for repatriated Rwandans, which has been extended to include other vulnerable groups such as foreign refugees (O'Connor, 2013). The minister for Disaster Management and Refugee Affairs (MIDIMAR), Seraphine Mukantabana has summarised this community-integrated approach as follows: 
'We have introduced community-integrated approach whereby programs meant to benefit refugees have to also benefit local communities and programs for citizens' development benefit refugees.' (MIDIMAR, 2014)

The long-term goal of this approach is to implement measures that mutually benefit different segments of the society, to stimulate the socio-economic inclusion of refugees and to reduce their dependency on humanitarian aid. In practice, however, the freedom of movement and the access to employment opportunities for refugees are limited by bureaucratic procedures and costs (Bilgili \& Loschmann, 2018; Easton-Calabria \& Lindsay, 2013). As a result, many of the Congolese refugees remain dependent on humanitarian aid for decades (Hovil, 2011). Nonetheless, Rwanda's comparatively inclusive and unrestrictive system makes it a particularly interesting case study, allowing us to observe the social implications of protracted refugee hosting in a context where there are few official policies blocking interaction and cooperation between hosts and refugees. Hence, it may be interpreted as an example for what happens to community social life when, at least in principle, social interaction between locals and refugees is unrestricted.

\section{Methodology}

Data

The data used in this study were gathered through both household and community surveys as well as focus group discussions (FGDs) implemented in May 2016 across multiple locations in Rwanda. The surveys and FGDs were conducted around the camps of Gihembe, Kigeme and Kiziba. The camps were chosen for accommodating the largest Congolese refugee populations in the country as illustrated in Table 1, as well as for representing a diverse range of contextual factors. For instance, the Kiziba and Gihembe camps mostly host protracted refugees who arrived in the late 90s, whereas the Kigeme camp only opened its doors in 2012. Differences are also found in the geographical characteristics of the locations. Kiziba, for example, is located several hours drive from the nearest commercial hub, Kibuye, making it the most remote of the three camps. Gihembe and Kigeme, by contrast, are located along main national roads fairly close to important cities, Byumba and Gikongoro, respectively. The differences in these characteristics among the three camps can be expected to provide markedly different potential for interaction between refugees and host communities.

Host communities were included in the sample primarily based on their distance from each camp. ${ }^{2}$ Figure 2 shows the research design used to define potential candidates for enumeration, including all cells located within a $10 \mathrm{~km}$ radius from a camp

Table 1 Breakdown of Congolese refugee camps in Rwanda

\begin{tabular}{lll}
\hline Camp & Year Established & Total Population \\
\hline Kigeme & 2012 & 18,646 \\
Kiziba & 1996 & 17,155 \\
Gihembe & 1997 & 14,205 \\
Nyabiheke & 2005 & 13,918 \\
Mugombwa & 2014 & 8319 \\
\hline
\end{tabular}

Source: MIDIMAR (2016); UNHCR (2018b) 


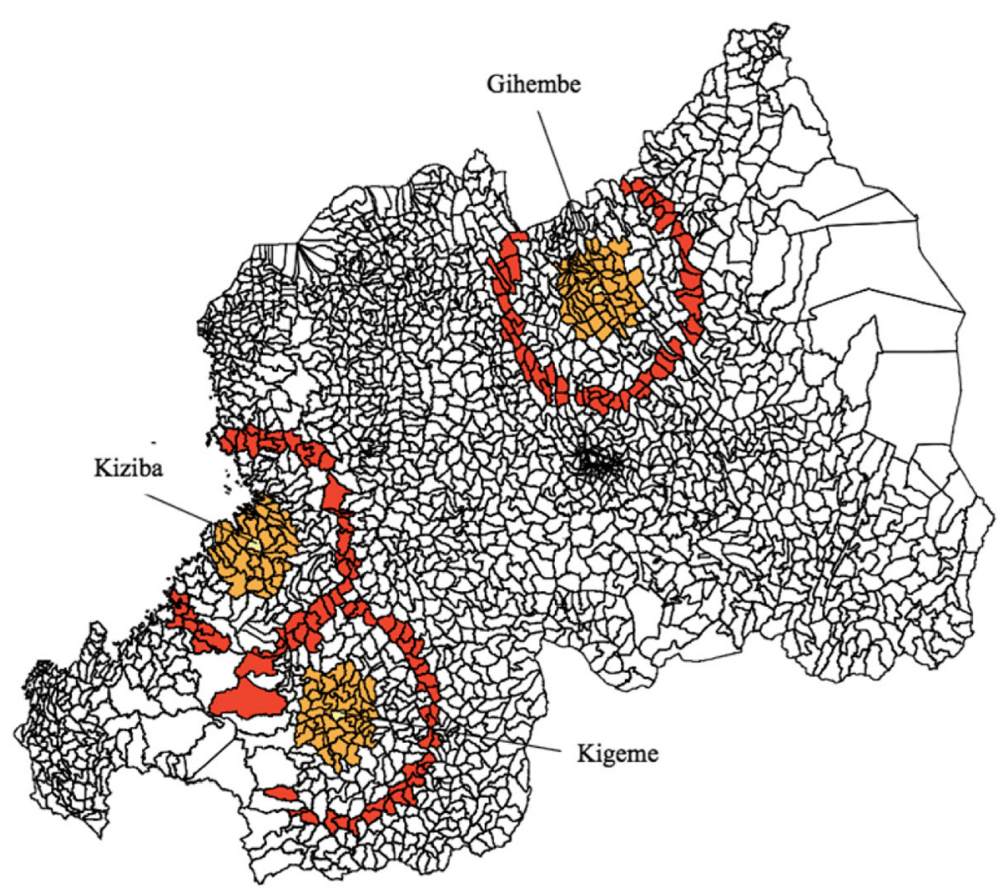

Fig. 2 Sampling strategy at the cell level. Legend: Note: Own generation based on publicly available administrative GIS data. Yellow cells indicate the location of each refugee camp. Orange cells are those within $10 \mathrm{~km}$ of each camp. Red cells are those above $20 \mathrm{~km}$ of each camp

(indicated in orange) and the same absolute number of cells from $20 \mathrm{~km}$ onwards (indicated in red). ${ }^{3}$ From the resulting list of eligible cells, we randomly selected four from both the within $10 \mathrm{~km}$ and the above $20 \mathrm{~km}$ areas around each camp and chose one community in each with the largest population. ${ }^{4}$ Next, households were randomly chosen for enumeration from a master list of all households located in the selected community, created in consultation with a community representative. Household surveys were conducted by an adult member of the household who could provide detailed information on all members of the household as well as relevant household characteristics (e.g. housing, economic situation). The household respondent also provided their personal opinion for more subjective questions like the ones used in this study.

As for the FGDs, two focus group discussions took place in a randomly chosen community from both the within $10 \mathrm{~km}$ and over $20 \mathrm{~km}$ areas from each camp, resulting in 12 discussions in total. Each group was comprised of six members, one being made up entirely of women and the other men. The groups were split by gender due to the concerns raised by local stakeholders that female participants might feel hesitant to voice their opinion in the presence of male participants. The discussions were led by a local moderator who was assisted by a dedicated note-taker. The moderator was provided with an interview guide in order to steer the discussion towards certain topics of interest related to our research questions, however the open nature of the discussion allowed participants freedom to emphasise and expand on issues they saw of particular importance. The discussions were conducted entirely in the local language, Kinyarwanda, and were transcribed and translated by the note-taker afterwards. 


\section{Empirical approach and description of variables}

The empirical approach both from a quantitative and qualitative perspective relies on the comparison of households within communities that are more vs. less 'exposed' to refugees due to their proximity to a refugee camp. This $10 \mathrm{~km}$ vs. $20 \mathrm{~km}$ setup was decided following pre-survey site visits and extensive discussions with stakeholders on the ground in order to gauge a high vs. low potential for interaction between refugees and host communities. As Alloush, Taylor, Gupta, Valdes, \& Gonzalez-Estrada (2017, p. 334) explain in their own study focusing exclusively on the $10 \mathrm{~km}$ area, "A 10-kilometer radius captures the main markets in which refugees transact. Given poor transportation infrastructure, refugees rarely engage directly with markets outside this radius." The distinction in the sample between 10 and $20 \mathrm{~km}$ communities serves to provide a counterfactual scenario, therefore our variable of interest indicates whether the household is located in a community nearby $(<10 \mathrm{~km})$ or further from $(>20 \mathrm{~km})$ a refugee camp. However, we also look across the three specific camp areas in order to see notable differences based on local context.

The outcomes used to gauge social life around the camps include subjective safety, formal and informal social networks, and trust in various groups. Subjective safety is assessed by asking the respondent 'Do you currently feel safe in this community?' with possible responses on a five-point Likert scale: 'Not at all safe'; 'A little safe'; 'Neutral'; 'Mostly safe'; and 'Completely safe'. For the statistical analysis, we construct a binary version of the variable which takes a value of one for the latter two response choices and zero for the former two. Having a formal network is defined as the respondent being an active member of at least one community organization, for example an agricultural cooperative, a trader's association or women's association, among others. Having an informal network is determined by the respondent having at least one person beyond their immediate household whom they could count on for sudden financial help. Trust indicators are measured in relation to different segments of society: the respondent's own community, refugees and IOs or NGOs. Similar to subjective safety, we use a constructed binary version of trust variable that takes a value of one if the respondent answered 'Quite a lot of trust' or 'Completely trust', and zero if 'Little trust' or 'No trust at all'.

In line with previous research that highlights differences in experiences driven by individual background characteristics, we account for potential confounding factors by including a variety of controls in all models. At the individual level, we control for the respondent's gender and marital status (one if married, either monogamously or polygamously, and zero otherwise) and literacy. At the household level, we include a binary variable measuring whether the respondent's household has at least one member who is employed in paid work, total monthly income (in Rwandan Franc) normalized using the inverse hyperbolic sine transformation, the share of children (as compared to adults) in the household, and the size of the household. Finally, we control for the closest refugee camp to account for location-specific differences.

In the following section, we present the results beginning with a descriptive account of the sample and mean differences among the outcomes in question based on distance to a refugee camp. We next report the estimates from a logistic regression analysis ${ }^{5}$ controlling for individual and household level factors, indicating the influence of residing in proximity to a camp in general as well as to a specific camp in particular using interaction terms. Finally, to triangulate and deepen our 
findings we review relevant evidence coming out of the FGDs which provide valuable insight.

\section{Results}

\section{Descriptive analysis}

We first identify the descriptive mean differences in respondent and household characteristics in communities nearby $(<10 \mathrm{~km})$ versus further from $(>20 \mathrm{~km})$ a refugee camp.

Table 2 presents the demographic and socio-economic characteristics that serve as controls in our models. By design, host communities of varying distance to a nearby camp are represented roughly equally among respondents, as are the three camps, Gihembe, Kiziba and Kigeme. Female respondents are slightly overrepresented, around $59 \%$, across both groups based on distance to the nearest camp. There is no difference in terms of the average age of the respondents per group. Around $70 \%$ of respondents are married, and roughly two-thirds are literate in both groups. Over $90 \%$ of households in both communities have at least one member who is employed in paid work with that share slightly higher for those further from a camp. The average share of children per adult within the household is close to being balanced in both groups, as is the average household size of five individuals. The most notable difference between the two groups is in the monthly household income, with households in close proximity to a camp producing an average monthly income nearly twice as high as that of households further away (49,000 vs. 27,000 RWF; equivalent to roughly 56 vs. 30 US dollars).

Table 3 reports the descriptive mean differences in relation to outcome variables of interest. We find that the level of perceived safety is roughly the same in communities nearby and further away from a refugee camp. The share of people with access to a formal network, namely formal membership in an organization, is just under half for those living nearby the camps and exactly half for those living further away. In terms of

Table 2 Summary statistics of the sample, by distance from a refugee camp

\begin{tabular}{|c|c|c|c|c|}
\hline & \multicolumn{2}{|l|}{$<10 \mathrm{~km}$} & \multicolumn{2}{|l|}{$>20 \mathrm{~km}$} \\
\hline & Freq./Mean & Perc./SD & Freq./Mean & Perc./SD \\
\hline Female & 234 & 0.59 & 202 & 0.59 \\
\hline Age & 44.95 & 15.19 & 44.71 & 15.57 \\
\hline Married & 290 & 0.73 & 236 & 0.69 \\
\hline Literate & 263 & 0.66 & 225 & 0.66 \\
\hline At least one employed member & 356 & 0.90 & 327 & 0.95 \\
\hline Monthly household income (RWF) & $48,737.98$ & $139,347.30$ & $27,054.82$ & $46,648.19$ \\
\hline Share of children (per adults) & 1.02 & 0.90 & 0.97 & 0.84 \\
\hline Household size & 4.83 & 2.07 & 4.50 & 2.10 \\
\hline \multicolumn{5}{|l|}{ Closest refugee camp } \\
\hline Gihembe & 150 & 0.38 & 136 & 0.40 \\
\hline Kigeme & 107 & 0.27 & 80 & 0.23 \\
\hline Kiziba & 140 & 0.35 & 127 & 0.37 \\
\hline $\mathrm{N}$ & 397 & 53.65 & 343 & 46.35 \\
\hline
\end{tabular}


Table 3 Descriptive differences in outcome variables, by distance from a refugee camp

\begin{tabular}{|c|c|c|c|c|}
\hline & \multicolumn{2}{|c|}{$<10 \mathrm{~km}$} & \multicolumn{2}{|c|}{$>20 \mathrm{~km}$} \\
\hline & Freq. & Perc. & Freq. & Perc. \\
\hline Feel safe in the community & 346 & 0.87 & 301 & 0.88 \\
\hline Formal network & 176 & 0.44 & 172 & 0.50 \\
\hline Informal network & 200 & 0.50 & 139 & 0.41 \\
\hline Trust in people from own community & 320 & 0.81 & 294 & 0.86 \\
\hline Trust in IOs and NGOs & 364 & 0.92 & 314 & 0.92 \\
\hline Trust in refugees in Rwanda & 328 & 0.83 & 271 & 0.79 \\
\hline $\mathrm{N}$ & 397 & 53.65 & 343 & 46.35 \\
\hline
\end{tabular}

Note: mean and standard deviation are reported for continuous variables: 'Age', 'Share of children (per adults)', 'Monthly household income (RWF)', and 'Household size'

informal networks, that is being able to count on someone outside the household when in financial need, the difference is slightly larger: about half of the respondents within $10 \mathrm{~km}$ can count on help compared to $41 \%$ outside of $20 \mathrm{~km}$.

Trust outcomes are fairly high in general - around or over $80 \%$ in all three categories - and are roughly similar regardless of proximity to refugee camp. The most notable differences are found for trust in own community, for which the share of 'trusting' respondents is somewhat lower in nearby a refugee camp, $81 \%$, compared to those further away, $86 \%$.

In summary, the descriptive analysis of the household data reveals little notable differences between local communities that are closer and farther away from refugee camps.

Alternatively, disaggregating the data by each of the refugee camps instead of distance to the nearest refugee camp shows similar variation across the three areas (see Table 4). Namely, while in Kiziba every second person has access to informal network for assistance, this share goes down to $41 \%$ in Gihembe and Kigeme. At the same time, feeling of safety seem to be lowest in Kiziba relative to the other two camps, but still within a quite narrow range.

\section{Quantitative analysis}

Going a step further, we now turn to the results of logistic regression analysis with models controlling for the general demographic and socio-economic characteristics previously described and shown in Table 2. Overall estimates, reported as odds ratios,

Table 4 Descriptive differences in outcome variables, by closest refugee camp

\begin{tabular}{|c|c|c|c|c|c|c|}
\hline & \multicolumn{2}{|c|}{ Gihembe } & \multicolumn{2}{|c|}{ Kigeme } & \multicolumn{2}{|l|}{ Kiziba } \\
\hline & Freq. & Perc. & Freq. & Perc. & Freq. & Perc. \\
\hline Feel safe in the community & 261 & 0.91 & 166 & 0.89 & 220 & 0.82 \\
\hline Formal network & 123 & 0.43 & 99 & 0.53 & 126 & 0.47 \\
\hline Informal network & 116 & 0.41 & 80 & 0.43 & 143 & 0.54 \\
\hline Trust in people from own community & 242 & 0.85 & 157 & 0.84 & 215 & 0.81 \\
\hline Trust in IOs and NGOs & 272 & 0.95 & 166 & 0.89 & 240 & 0.90 \\
\hline Trust in refugees in Rwanda & 231 & 0.81 & 144 & 0.77 & 224 & 0.84 \\
\hline $\mathrm{N}$ & 286 & 38.65 & 187 & 25.27 & 267 & 36.08 \\
\hline
\end{tabular}


Table 5 Logistic regression analysis, by distance from a refugee camp (odds ratios)

\begin{tabular}{|c|c|c|c|c|c|c|}
\hline & $\begin{array}{l}\text { Feel safe in } \\
\text { the } \\
\text { community }\end{array}$ & $\begin{array}{l}\text { Formal } \\
\text { network }\end{array}$ & $\begin{array}{l}\text { Informal } \\
\text { network }\end{array}$ & $\begin{array}{l}\text { Trust in people from } \\
\text { own community }\end{array}$ & $\begin{array}{l}\text { Trust in IOs } \\
\text { and NGOs }\end{array}$ & $\begin{array}{l}\text { Trust in } \\
\text { refugees in } \\
\text { Rwanda }\end{array}$ \\
\hline & (1) & $(2)$ & (3) & (4) & (5) & (6) \\
\hline \multirow{2}{*}{$\begin{array}{l}\text { Camp proximity }< \\
10 \mathrm{~km}\end{array}$} & 0.98 & 0.80 & $1.41^{* *}$ & $0.64^{* *}$ & 0.97 & 1.33 \\
\hline & $(0.22)$ & $(0.12)$ & $(0.22)$ & $(0.13)$ & $(0.26)$ & $(0.26)$ \\
\hline \multirow[t]{2}{*}{ Gihembe } & $2.27^{* * *}$ & 0.89 & $0.54^{* * *}$ & 1.35 & $2.24^{* *}$ & 0.77 \\
\hline & $(0.62)$ & $(0.16)$ & $(0.10)$ & $(0.32)$ & $(0.78)$ & $(0.18)$ \\
\hline \multirow[t]{2}{*}{ Kigeme } & $1.72^{*}$ & 1.34 & $0.69^{*}$ & 1.32 & 0.93 & $0.59^{* *}$ \\
\hline & $(0.48)$ & $(0.27)$ & $(0.14)$ & $(0.34)$ & $(0.29)$ & $(0.14)$ \\
\hline \multirow[t]{2}{*}{ Female } & 0.72 & 0.89 & 1.13 & $0.65^{*}$ & $1.82^{* *}$ & 0.79 \\
\hline & $(0.18)$ & $(0.14)$ & $(0.19)$ & $(0.14)$ & $(0.51)$ & $(0.16)$ \\
\hline \multirow[t]{2}{*}{ Age } & 1.01 & $1.01^{*}$ & 1.00 & $1.02^{* *}$ & 1.01 & 1.00 \\
\hline & $(0.01)$ & $(0.01)$ & $(0.01)$ & $(0.01)$ & $(0.01)$ & $(0.01)$ \\
\hline \multirow[t]{2}{*}{ Married } & 0.73 & 0.79 & 1.14 & 0.93 & 0.83 & 0.76 \\
\hline & $(0.22)$ & $(0.15)$ & $(0.22)$ & $(0.23)$ & $(0.29)$ & $(0.19)$ \\
\hline \multirow[t]{2}{*}{ Literate } & 1.08 & $1.74^{* * *}$ & $1.74^{* * *}$ & 0.77 & 1.06 & $0.60^{* *}$ \\
\hline & $(0.29)$ & $(0.31)$ & $(0.32)$ & $(0.19)$ & $(0.32)$ & $(0.14)$ \\
\hline \multirow{2}{*}{$\begin{array}{l}\text { At least one } \\
\text { employed } \\
\text { member }\end{array}$} & $2.38^{* *}$ & $2.21^{* * *}$ & 0.77 & 0.70 & 0.43 & 0.94 \\
\hline & $(0.89)$ & $(0.68)$ & $(0.23)$ & $(0.30)$ & $(0.30)$ & $(0.36)$ \\
\hline \multirow{2}{*}{$\begin{array}{l}\text { Monthly } \\
\text { household income } \\
\text { (RWF) }\end{array}$} & 1.00 & 1.00 & $1.00^{* * *}$ & 1.00 & 1.00 & 1.00 \\
\hline & $(0.00)$ & $(0.00)$ & $(0.00)$ & $(0.00)$ & $(0.00)$ & $(0.00)$ \\
\hline \multirow{2}{*}{$\begin{array}{l}\text { Share of children } \\
\text { (per adults) }\end{array}$} & 1.17 & 1.07 & $1.28^{* *}$ & 1.04 & 0.98 & 0.92 \\
\hline & $(0.20)$ & $(0.11)$ & $(0.13)$ & $(0.16)$ & $(0.16)$ & $(0.11)$ \\
\hline \multirow[t]{2}{*}{ Household size } & 0.98 & 1.08 & 0.95 & 1.10 & 1.09 & 0.98 \\
\hline & $(0.06)$ & $(0.05)$ & $(0.04)$ & $(0.07)$ & $(0.09)$ & $(0.05)$ \\
\hline Pseudo-R2 & 0.04 & 0.03 & 0.05 & 0.04 & 0.04 & 0.03 \\
\hline $\mathrm{N}$ & 740 & 740 & 740 & 740 & 740 & 740 \\
\hline
\end{tabular}

are presented in Table 5 which highlight the influence of living in proximity to a refugee camp, less than $10 \mathrm{~km}$ vs greater than $20 \mathrm{~km}$. Alternatively, Table 6 reports the same estimates but with an interaction term between camp proximity and each individual refugee camp to identify differences across the three contexts. Since we are reporting odds ratios, a coefficient greater than one points to a positive association. Robust standard errors are clustered at the community level and reported in parentheses.

First, model 1 in Table 5 finds no statistically significant association between living nearby a refugee camp and perceptions of safety within a community. Still, regardless of proximity to the camp, respondents outside of Gihembe camp seem to feel greater security in comparison to the reference group of respondents outside Kiziba. Looking at the interaction terms in Table 6, even though there is evidence that respondents within $10 \mathrm{~km}$ of Kigeme camp feel their community is less safe in comparison to respondents outside of $20 \mathrm{~km}$ from Kigeme camp, this relationship is only marginally statistically significant at the $10 \%$ level.

In the case of formal networks gauged by membership in a local organization, proximity and camp location are not statistically significant overall. Yet, as shown in model 
Table 6 Logistic regression analysis, by closest refugee camp (odds ratios)

\begin{tabular}{|c|c|c|c|c|c|c|}
\hline & $\begin{array}{l}\text { Feel safe in the } \\
\text { community } \\
\text { (1) }\end{array}$ & $\begin{array}{l}\text { Formal } \\
\text { network } \\
\text { (2) }\end{array}$ & $\begin{array}{l}\text { Informal } \\
\text { network } \\
\text { (3) }\end{array}$ & $\begin{array}{l}\text { Trust in people from } \\
\text { own community } \\
\text { (4) }\end{array}$ & $\begin{array}{l}\text { Trust in IOs } \\
\text { and NGOs }\end{array}$ & $\begin{array}{l}\text { Trust in refugees } \\
\text { in Rwanda } \\
\text { (6) }\end{array}$ \\
\hline \multirow{2}{*}{$\begin{array}{l}<10 \mathrm{~km} \text { from } \\
\text { Gihembe }\end{array}$} & 1.41 & $0.36^{* * *}$ & 0.74 & 0.59 & 1.39 & 0.74 \\
\hline & $(0.61)$ & $(0.09)$ & $(0.19)$ & $(0.20)$ & $(0.77)$ & $(0.23)$ \\
\hline \multirow[t]{2}{*}{$<10 \mathrm{~km}$ from Kigeme } & $0.38^{*}$ & $2.32^{* * *}$ & $2.47^{* * *}$ & $0.41^{* *}$ & 0.61 & 1.53 \\
\hline & $(0.20)$ & $(0.73)$ & $(0.78)$ & $(0.18)$ & $(0.30)$ & $(0.56)$ \\
\hline \multirow[t]{2}{*}{$<10 \mathrm{~km}$ from Kiziba } & 1.19 & 0.88 & $1.84^{* *}$ & 0.88 & 1.13 & $2.36^{* *}$ \\
\hline & $(0.39)$ & $(0.22)$ & $(0.47)$ & $(0.28)$ & $(0.47)$ & $(0.83)$ \\
\hline \multirow[t]{2}{*}{ Gihembe } & $2.10^{*}$ & 1.39 & 0.84 & 1.69 & 2.06 & 1.33 \\
\hline & $(0.80)$ & $(0.36)$ & $(0.22)$ & $(0.59)$ & $(0.99)$ & $(0.42)$ \\
\hline \multirow[t]{2}{*}{ Kigeme } & $3.56^{* *}$ & 0.77 & $0.57^{*}$ & $2.13^{*}$ & 1.31 & 0.70 \\
\hline & $(1.84)$ & $(0.23)$ & $(0.18)$ & $(0.94)$ & $(0.63)$ & $(0.25)$ \\
\hline \multirow[t]{2}{*}{ Female } & 0.77 & 0.81 & 1.09 & $0.68^{*}$ & $1.92^{* *}$ & 0.79 \\
\hline & $(0.19)$ & $(0.13)$ & $(0.19)$ & $(0.15)$ & $(0.54)$ & $(0.17)$ \\
\hline \multirow[t]{2}{*}{ Age } & $1.01^{*}$ & 1.01 & 1.00 & $1.02^{* *}$ & 1.01 & 1.00 \\
\hline & $(0.01)$ & $(0.01)$ & $(0.01)$ & $(0.01)$ & $(0.01)$ & $(0.01)$ \\
\hline \multirow[t]{2}{*}{ Married } & 0.72 & 0.76 & 1.11 & 0.93 & 0.83 & 0.75 \\
\hline & $(0.21)$ & $(0.15)$ & $(0.22)$ & $(0.23)$ & $(0.29)$ & $(0.18)$ \\
\hline \multirow[t]{2}{*}{ Literate } & 1.09 & $1.74^{* * *}$ & $1.75^{* * *}$ & 0.78 & 1.07 & $0.60^{* *}$ \\
\hline & $(0.30)$ & $(0.31)$ & $(0.32)$ & $(0.19)$ & $(0.32)$ & $(0.14)$ \\
\hline \multirow{2}{*}{$\begin{array}{l}\text { At least one } \\
\text { employed member }\end{array}$} & $2.55^{* *}$ & $2.01^{* *}$ & 0.70 & 0.69 & 0.45 & 0.84 \\
\hline & $(0.97)$ & $(0.63)$ & $(0.22)$ & $(0.30)$ & $(0.31)$ & $(0.33)$ \\
\hline \multirow{2}{*}{$\begin{array}{l}\text { Monthly household } \\
\text { income (RWF) }\end{array}$} & 1.00 & 1.00 & $1.00^{* * *}$ & 1.00 & 1.00 & 1.00 \\
\hline & $(0.00)$ & $(0.00)$ & $(0.00)$ & $(0.00)$ & $(0.00)$ & $(0.00)$ \\
\hline \multirow{2}{*}{$\begin{array}{l}\text { Share of children } \\
\text { (per adults) }\end{array}$} & 1.19 & 1.05 & $1.26^{* *}$ & 1.04 & 0.98 & 0.90 \\
\hline & $(0.21)$ & $(0.11)$ & $(0.13)$ & $(0.16)$ & $(0.17)$ & $(0.11)$ \\
\hline \multirow[t]{2}{*}{ Household size } & 0.99 & 1.08 & 0.95 & $1.10^{*}$ & 1.10 & 0.98 \\
\hline & $(0.06)$ & $(0.05)$ & $(0.04)$ & $(0.07)$ & $(0.09)$ & $(0.05)$ \\
\hline Pseudo-R2 & 0.04 & 0.05 & 0.07 & 0.04 & 0.04 & 0.04 \\
\hline N & 740 & 740 & 740 & 740 & 740 & 740 \\
\hline
\end{tabular}

${ }^{* * *} p<0.01,{ }^{* *} p<.05,{ }^{*} p<0.10$. Kiziba is the reference camp. Standard errors in parentheses are robust

2 of Table 6, the camp-specific effect derived by interacting proximity and camp location reveals that living nearby Kigeme camp in comparison to further away increases the chances of having a formal network by a factor of 2.32. Conversely, for Gihembe, living in the vicinity of the camp lowers the odds of having a formal network by a factor of 0.36. The proximity is not statistically significant in the case of the Kiziba camp.

As for informal networks measured by whether the respondent is able to count on someone outside the household in times of financial need, we find an overall statistically significant result based on proximity to a refugee camp. Living within $10 \mathrm{~km}$ of a camp relative to outside $20 \mathrm{~km}$ increases the chances of being able to count on an informal network by a factor of 1.41. The camp-specific effects, however, show that this result is largely driven by households living nearby Kigeme camp and to a lesser extent Kiziba. Namely, the odds of having access to informal social network is higher by a factor of 2.47 for households living closer to Kigeme refugee camp in comparison to living further away from it. It is important to note however that overall, compared to those living around Kiziba camp, households around Kigeme are less likely to have access to 
informal social networks. In other words, the results indicate that outside Kigeme access to informal social networks are relatively low in general, but this is more so the case for those living further away from the camp.

In terms of measures of trust, we find mixed results. Overall, model 4 in Table 5 indicates that residing close by a camp is associated with lower levels of trust within ones' own community. ${ }^{6}$ However, Table 6 illustrates how this negative result is largely driven by respondents outside Kigeme camp, with no relationship in the case of Gihembe and Kiziba. Alternatively, we find no relationship with respect to trust in IOs or NGOs, nor the refugee population itself. On the other hand, respondents living within $10 \mathrm{~km}$ of Kiziba camp in particular have considerably higher levels of trust towards refugees compared to respondents further away from the same camp, suggesting, at least in that case, a link between exposure and warmer relations.

Overall, the quantitative analysis provides mixed results and does not point to a consistent positive or negative social impact due to living nearby a refugee camp. Indeed, many of the model estimates are statistically insignificant which implies that the refugee population does not influence the social lives of local hosts in obvious ways, good or bad, that we are able to capture with our household survey data. This may be due to the limited statistical power with a sample of this size, or the difficulty in measuring principally subjective social indicators. Alternatively, the influence of refugees on the lives of hosts may be more subtle and therefore likely to come out of nuanced qualitative approaches to which we now turn.

\section{Perspective of locals regarding the influence of living close to a refugee camp on the social life in their community}

The underlying assumption for the previous analysis was that exposure to and increased chances of interaction with refugee populations may have an influence on the social life within a community. Besides local differences, the quantitative results overall indicate that those living closer to a refugee camp do not necessarily feel less safe, have fewer formal social networks, or have less trust in refugees, IOs or NGOs. They do however seem to have more informal social networks. In this section, we seek to give a more informed explanation to these results on the basis of qualitative evidence derived from FGDs. In particular, we identify three main reasons why relations between refugees and hosts nearby the camps appear by-and-large constructive: cultural proximity to refugee population, increased social and economic interactions over time, and recognition of the importance of support given to refugees by IOs and NGOs.

To begin with, participants of FGDs living nearby the refugee camps convey a narrative of positive social and economic interaction between refugees and host communities. As mentioned, we may expect a degree of pre-existing cultural closeness between the two groups since most Congolese refugees already lived within close proximity to Rwanda before becoming refugees, share the language of locals, and often may even have Rwandan ancestry (Stearns, 2012; UNHCR, 2014). Focus group discussants generally confirmed the social closeness between locals and refugees:

Those refugees have already become Rwandans. The only difference arises from the fact that they are located in the camp. Otherwise, we consider them as Rwandans.

-Participant 1, Kiziba community $<10 \mathrm{~km}$ 
While cultural similarities may have facilitated the process of acceptance, this is not explicitly mentioned: refugees still had to 'become' Rwandans, an achievement that may have also been enabled by the long timeframe in this protracted hosting experience. Another facilitating factor mentioned is the memory of Rwanda's own not-too-distant conflict during which Rwandans themselves were refugees in the DRC's North Kivu area:There is no problem since we once were refugees too... that is why we should consider them as our relatives.

-Participant 3, Kiziba community $<10 \mathrm{~km}$

At the same time, the fact that refugees and host communities have the opportunity to interact both in economic and social spheres of everyday life, for example in the local market place or schools, seems to play a role in the lack of tension and good relations. A common observation among focus group discussants is the building of trust over time due to increased economic interactions. Multiple participants recall fear, conflicts or negative incidents related to refugees when they first arrived, but report improved relations and a lack of problems in the present:

When [the refugees] arrived here, we were afraid of them since they are refugees but now we even work with them.

-Participant 7, Kiziba community $<10 \mathrm{~km}$

Likewise, participants stressed the role of cooperation in economic activities in the strengthened relationship:

They didn't have much to trade when they first arrived. But after they started receiving food, they could sell it to us so that they could also get some green vegetables.

-Participant 4, Gihembe community $<10 \mathrm{~km}$

(...) But then we share[d] the production; he gives the morning milk to his kids and then I give the evening one to mine. And this creates a bond between us.

-Participant 4, Kigeme community $<10 \mathrm{~km}$

These accounts on the positive role of extended contact and economic cooperation provide compelling support for the Rwandan government's integrative policy towards refugees, which allows them to interact with locals in multiple aspects of everyday life. Aside from constructive economic interaction, it appears that the ability of refugees to utilise local social institutions also contributes to better relations and improved social cohesion. Focus group participants, for example, routinely express the positive nature of refugees attending local schools and how it has led to good relations: 
they interact. They have a good relationship, (...) and this creates also love and interaction between their parents.

-Multiple participants, Kigeme community $<10 \mathrm{~km}$

Finally, social cohesion within the community is perceived to be supported by the contributions of the IOs and NGOs that are working with and for refugees. Contrary to what one might expect, locals seem to be predominantly supportive of refugees receiving aid not only out of sympathy for their plight, but also because they believe that the provision of aid helps prevent potential security problems caused by refugees who would otherwise turn to theft and begging. This may help explain the lack of perceived safety threats and trust issues towards refugees in communities nearby the camps. Some key examples include:

Security is better when refugees are well treated. You understand that they can disturb the country's security; if they are dying of hunger, they can steal from people in this community, and their kids cannot study well with an empty stomach. That is the reason they really need support.

-Participant 2, Gihembe community $>20 \mathrm{~km}$

If they are not supported they don't come out [of] the camp to steal from the community, (...) they don't come to us to scrounge from the community, and they are not scattered everywhere. We are secure when they are supported. It is like supporting us too.

-Multiple participants, Kigeme $<10 \mathrm{~km}$

It appears, therefore, that continued support for refugees is important not only to help refugees get back on their feet, but also to avoid negative incidents with host communities. In short, input of respondents from FGDs helped us identify three main reasons why cohesion, inclusiveness and peace are not necessarily undermined by the presence of Congolese refugees in areas close to refugee camps.

\section{Conclusion}

The findings of our study challenge the general assumption that the presence of refugees will damage social cohesion within refugee hosting communities. In fact, we learn that even in case of initial apprehension, over time, refugees and host communities may build close social relations and sustain a peaceful and inclusive social environment. The objective of this paper has been to look into this issue in more depth and understand in a comprehensive manner how living in close proximity to a Congolese refugee camp has an influence on social life within Rwandan local communities. We paid particular attention to differences among multiple areas of social life including subjective safety, engagement in formal and informal social networks and trust in own community, organizations and refugees themselves. Although the cross-sectional nature of our analysis does not allow us to draw causal relationships, we sought to identify first 
whether differences existed between host communities living at varying distances to refugee camps and second the mechanisms through which positive outcomes are achieved and maintained based on input from FGDs conducted with locals.

Overall, feelings of safety, access to formal social networks and trust to refugees and IOs or NGOs do not seem to be related to the proximity to refugee camps. In the long run, we found that Rwandan locals' feelings of safety were not affected by the presence of refugees, which is an important contribution to the highly mixed and objective riskfocused previous evidence (e.g. Rutinwa \& Kamanga, 2003; UNHCR, 2003). Our positive findings with regards to effect on informal social networks fall in line with Gesthuizen et al.'s (2009) cross-country comparison and Whitaker's (1999) results from Tanzania. Beyond general associations, our diverging camp-specific results for both formal and informal networks echo Gesthuizen et al.s (2009) and Kesler and Bloemraad's (2010) final takeaway that local context plays a key role in shaping these outcomes. In line with Delhey and Newton (2005), Hooghe et al. (2008), and Kesler and Bloemraad (2010) we find some indication of a negative association with community trust, but the fact that this general result is driven by a single locality challenges the existence of a general negative link and points, instead, to the importance of local context. The fact that more exposure to refugees had an either null or even positive link to trust in refugees may be explained by the positive interactions between the two groups that became apparent from the focus group discussions (building on Laurence \& Bentley, 2018). All in all, the study contradicts Putnam's (2007) Hunkering-Down Theory: there is no consistent empirical evidence to suggest negative social implications of hosting refugees in Rwanda.

These results are an important contribution to the scarce empirical literature available concerning the social implications of hosting refugees in low-income countries, but are not without their limitations. The common cultural heritage of our hosts and refugee populations makes our case study particularly relevant to other contexts with a history of circular movements or internally displaced populations. On the other hand, the cultural similarities between Congolese refugees and Rwandan hosts make the findings less generalizable for settings where there are considerable differences across the two groups. The extended timeframe and the reciprocal refugee hosting experience between the two groups is also particular to our case. Nonetheless, these particularities shed light the importance of the contextual element, confirming the need to zoom into further diverse local contexts in developing countries and appropriately identify causal mechanisms that may differ across settings. Future research may also look more indepth into objective and subjective measurements of social life and find ways to tackle the issue of socially biased answers regarding subjective assessment questions. For instance, the high occurrence of trust and feelings of safety in the various groups suggest that more scrutiny is needed for the measurement of such variables. Finally, research that is able to identify changes over time and address the same question in communities where there are more newly arrived refugees can be extremely important for the research field and for the identification of policy recommendations.

The long-term presence of Congolese refugees in Rwanda and their cultural proximity to the local population may have helped sustain a socially cohesive, inclusive and peaceful environment. However, qualitative evidence from the FGDs gives further ideas in terms of how to support social cohesion in host communities. Firstly, it is important 
to promote increased economic and social interactions between refugees and the locals. In this regard, despite the challenges it entails, the community integrated approach of the Rwandan government seems to be in the right direction. Secondly, refugee support by organizations should be continued until economic independence is achieved, because rather than leading to resentment by the locals, these support mechanisms are appreciated and are believed to decrease potential economic threats from the refugee populations. At the same time, to avoid potential resentment from vulnerable locals feeling overlooked in favour of refugees, it would be worth considering to provide comprehensive assistance to the community as a whole. In short, our mostly sanguine conclusions may be interpreted as evidence that offering refuge to desperate populations fleeing conflict does not have to be problematic even in the case of a country with limited resources.

\section{Endnotes}

${ }^{1}$ For historical reasons, the subject of ethnicity is generally avoided in Rwanda including in our own research tools. Furthermore, some Banyarwanda groups' Rwandan origins date back several generations. The proximity in culture and national/ethnic identity between refugees and hosts is thus difficult to assess, but we acknowledge its likelihood as an important characteristic of our case study. Nonetheless, evidence from cases of internal displacement shows that even co-national refugee inflows can affect host communities' social cohesion (Amuedo-Dorantes et al., 2018).

${ }^{2}$ For our purposes, we use 'community' to indicate the lowest administrative unit in Rwanda, otherwise known as a village.

${ }^{3} \mathrm{~A}$ cell is the second lowest administrative unit above the village. Country-wide data at the village level was not readily available; therefore, pre-defined randomization took place at the cell level.

${ }^{4}$ Population data at the village level for those selected cells was generously made available by the National Institute of Statistics Rwanda (NISR).

${ }^{5}$ We report estimates from a logistic regression analysis considering the binary nature of outcomes in question, however using a linear probability model (i.e. OLS) results in no qualitative difference in the results.

${ }^{6}$ When we do a robustness check of the result by including 'neutral' category as part of the individuals who have trust in their own community, this variable is not significant anymore, highlighting no negative association between living close to a refugee camp and trust in own community.

\section{Abbreviations}

DRC: The Democratic Republic of Congo; FGDs: Focus group discussions; IOs: International organisations; MIDIMAR: Minister for Disaster Management and Refugee Affairs (Rwanda); NGOs: Non-governmental organisations; RWF: Rwandan Francs; SD: Standard deviation; UNHCR: The UN Refugee Agency

\section{Acknowledgements}

This paper is a result of a project funded by the United Nations High Commissioner for Refugees (UNHCR), but which was independently carried out by researchers from the Maastricht Graduate School of Governance | UNU-MERIT. We are thankful of the UNHCR's sub-country office in Kigali, as well as the National Institute of Statistics Rwanda (NISR) for their support during fieldwork.

\section{Authors' contributions}

$V F, O B$ and $C L$ and contributed to writing the introduction. VF and $O B$ contributed to the literature review section titled 'Social cohesion in forced displacement contexts'. VF, OB and CL contributed to the sections titled 'Congolese refugees in Rwanda', 'Methods', and 'Results'. VF and CL implemented the data analysis including robustness checks. $V F, O B$ and $C L$ interpreted the findings in 'Results' and contributed to the conclusion. MS participated in discussions 
on the paper's approach and implementation of the project as the Principal Investigator of the larger project. All authors have read and approved the final manuscript.

\section{Funding}

The authors would like to acknowledge UNHCR for funding the data collection efforts on which this analysis relies.

\section{Availability of data and materials}

The datasets and related material (e.g. questionnaires, do-files) used for the study are available from the corresponding author on reasonable request.

\section{Competing interests}

The authors declare that they have no competing interests.

\section{Author details}

${ }^{1}$ School of Social Policy, University of Birmingham, Birmingham B15 2TT, UK. ${ }^{2}$ ERCOMER, Utrecht University, Heidelberglaan 1, 3584 CS Utrecht, the Netherlands. ${ }^{3}$ Maastricht Graduate School of Governance \& UNU-MERIT, Maastricht University, Maastricht, the Netherlands.

Received: 13 September 2018 Accepted: 3 June 2019

Published online: 06 August 2019

\section{References}

Alloush, M., Taylor, J. E., Gupta, A., Valdes, R. I. R., \& Gonzalez-Estrada, E. (2017). Economic life in refugee camps. World Development, 95, 334-347.

Allport, G. (1954). The nature of prejudice. New York: Doubleday.

Amuedo-Dorantes, C., Bansak, C., \& Pozo, S. (2018). Refugee admissions and public safety: are refugee settlement areas more prone to crime? (IZA discussion papers, No. 11612, p. 43). Bonn: IZA - Institute of Labor Economics.

Benos, N., \& Kammas, P. (2018). Workers of the world unite (or not?) The effect of ethnic diversity on the participation in trade unions. (MPRA Paper No. 84880; p. 26). Retrieved from https://mpra.ub.uni-muenchen.de/84880/.

Bilgili, Ö., \& Loschmann, C. (2018). Refugees and host communities in the Rwandan labour market. Forced Migration Review, $58,22-23$.

Christophersen, M., Liu, J., Thorleifsson, C. M., \& Tiltnes, A. A. (2013). Lebanese attitudes towards Syrian refugees and the Syrian crisis: Results from a national opinion poll (Fafo paper No. 2013:13). Retrieved from https://www.alnap.org/system/files/ content/resource/files/main/10179.pdf.

Collier, P., \& Hoeffler, A. (2004). Greed and grievance in civil war. Oxford Economic Papers, 56, 563-595.

Delhey, J., \& Newton, K. (2005). Predicting cross-national levels of social trust: Global pattern or nordic exceptionalism? European Sociological Review, 21(4), 311-327.

Depetris-Chauvin, E., \& Santos, R. J. (2018). Followed by violence: Forced immigration and homicides (Working Paper No. 513). Retrieved from http://economia.uc.cl/publicacion/followed-by-violence-forced-immigration-and-homicides/.

Easton-Calabria, E., \& Lindsay, A. (2013). Towards durable solutions for protracted Congolese refugees in Rwanda. Oxford Monitor of Forced Migration, 3(2), 58-66.

Feldmeyer, B., Madero-Hernandez, A., Rojas-Gaona, C. E., \& Sabon, L. C. (2019). Immigration, collective efficacy, social ties, and violence: Unpacking the mediating mechanisms in immigration effects on neighborhood-level violence. Race and Justice, 9(2), 123-150. https://doi.org/10.1177/2153368717690563.

Gesthuizen, M., van der Meer, T., \& Scheepers, P. (2009). Ethnic diversity and social capital in Europe: Tests of Putnam's thesis in European countries. Scandinavian Political Studies, 32(2), 121-142. https://doi.org/10.1111/j.1467-9477.2008.00217.x.

Goldschmidt, T. (2017). Immigration, social cohesion, and the welfare state studies on ethnic diversity in Germany and Sweden. Stockholm: Stockholm University.

Guay, J. (2015). Social cohesion between Syrian refugees and urban host communities in Lebanon and Jordan (disaster management 2020). World Vision International. Retrieved from: https://www.wvi.org/disaster-management/publication/ social-cohesion-between-syrian-refugees-and-urban-host-communities.

Harb, C., \& Saab, R. (2014). Social cohesion and intergroup relations: Syrian refugees and Lebanese nationals in the Bekaa and Akkar. Beirut: American University of Beirut and Save the Children. Retrieved from https://data2.unhcr.org/es/documents/ download/40814.

Hooghe, M., Reeskens, T., Stolle, D., \& Trappers, A. (2008). Ethnic diversity and generalized trust in Europe: A cross-national multilevel study. Comparative Political Studies, 42(2), 198-223. https://doi.org/10.1177/0010414008325286.

Hovil, L. (2011). Shadows of Return: The Dilemmas of Congolese Refugees in Rwanda. (Citizenship and Displacement in the Great Lakes Region, Working Paper 6). International Refugee Rights Initiative (IRRI). Retrieved from https://www.refworld. org/docid/53b3dc834.html.

Jacobsen, K. (2002). Livelihoods in conflict: The pursuit of livelihoods by refugees and the impact on the human security of host communities. International Migration, 40(5), 95-123.

Kesler, C., \& Bloemraad, I. (2010). Does immigration erode social capital? The conditional effects of immigration-generated diversity on trust, membership, and participation across 19 countries, 1981-2000. Canadian Journal of Political Science, 43(2), 319-347.

Kreibaum, M. (2016). Their suffering, our burden? How Congolese refugees affect the Ugandan population. World Development, 78, 262-287. https://doi.org/10.1016/j.worlddev.2015.10.019.

Laurence, J., \& Bentley, L. (2018). Countervailing contact: Community ethnic diversity, anti-immigrant attitudes and mediating pathways of positive and negative inter-ethnic contact in European societies. Social Science Research, 69, 83-110. https:// doi.org/10.1016/j.ssresearch.2017.09.007. 
Laurence, J., Schmid, K., \& Hewstone, M. (2019). Ethnic diversity, ethnic threat, and social cohesion: (re)-evaluating the role of perceived out-group threat and prejudice in the relationship between community ethnic diversity and intra-community cohesion. Journal of Ethnic and Migration Studies, 45(3), 395-418. https://doi.org/10.1080/1369183X.2018.1490638.

Masterson, D., \& Yasenov, V. (2018). Does halting refugee resettlement reduce crime? Evidence from the United States refugee ban (IPL Working Paper Series Working Paper No. 18-03). Retrieved from University website: https://osf.io/w2x7p.

Mavridis, D. (2015). Ethnic diversity and social capital in Indonesia. World Development, 67, 376-395. https://doi.org/10.1016/j. worlddev.2014.10.028.

Maystadt, J.-F., \& Verwimp, P. (2014). Winners and losers among a refugee-hosting population. Economic Development and Cultural Change, 62(4), 769-809. https://doi.org/10.1086/676458.

Mercy Corps (2013). Things fall apart: Political, economic and social instability in Lebanon (lessons for effective resilience programming). Mercy Corps. Retrieved from: https://www.mercycorps.org/sites/default/files/ MC\%20Lebanon\%20LivelihoodConflict_Assesment_\%20Full\%20Report\%200913.pdf.

MIDIMAR (2014, May 27). MIDIMAR launches 1000 days nutrition campaign in refugee camps. MIDIMAR [Press release]. Retrieved from https://reliefweb.int/report/rwanda/midimar-launches-1000-days-nutrition-campaign-refugee-camps.

MIDIMAR. (2016). Camps and transit centres. Retrieved from http://midimar.gov.rw/index.php?id=69

O'Connor, K. (2013). The politics of (re)-constructing and contesting Rwandan citizenship. (Refugee Studies Center Working Paper No. 92). Retrieved from https://www.rsc.ox.ac.uk/files/files-1/wp92-repatriation-reconstructing-contesting-rwandancitizenship-2013.pdf.

OECD (2011). Perspectives on global development 2012 social cohesion in a shifting world? (executive summary). Retrieved from http://www.oecd.org/site/devpgd2012/49067839.pdf.

Pettigrew, T. F. (1998). Intergroup contact theory. Annual Review of Psychology, 49, 65-85.

Porter, G., Hampshire, K., Kyei, P., Adjaloo, M., Rapoo, G., \& Kilpatrick, K. (2008). Linkages between livelihood opportunities and refugee-host relations: Learning from the experiences of Liberian camp-based refugees in Ghana. Journal of Refugee Studies, 21(2), 230-252. https://doi.org/10.1093/jrs/fen015.

Putnam, R. D. (2007). E pluribus unum: Diversity and community in the twenty-first century the 2006 Johan Skytte prize lecture. Scandinavian Political Studies, 30(2), 137-174.

REACH. (2014). Understanding Social Cohesion and Resilience in Jordanian Host Communities (Assessment Report). Retrieved from https://reliefweb.int/sites/reliefweb.int/files/resources/REACH_Social-Cohesion-Resilience-in-Jordanian-HostCommunities_FINAL.pdf.

Ruiz, I., \& Vargas-Silva, C. (2015). The labour market consequences of hosting refugees. Journal of Economic Geography, 16(3), 667-694.

Rutinwa, B., \& Kamanga, K. (2003). Impact of refugees in Northwestern Tanzania. Center for Study of Forced Migration: University of Dar es Salaam. Retrieved from https://repositories.lib.utexas.edu/handle/2152/4679.

Salehyan, I. (2007). Transnational rebels: Neighbouring states as sanctuary for rebel groups. World Politics, 59(2), 217-242.

Schmeidl, S. (2002). (Human) security dilemmas: Long-term implications of the Afghan refugee crisis. Third World Quarterly, 23(1), 7-29. https://doi.org/10.1080/01436590120114328.

Stanley, D. (2003). What Do We Know about Social Cohesion: The Research Perspective of the Federal Government's Social Cohesion Research Network. Canadian Journal of Sociology/Cahiers Canadiens de Sociologie, 28(1), p. 5-17. https://doi.org/ $10.2307 / 3341872$

Stearns, J. (2012). North Kivu: The background to conflict in north Kivu province of eastern Congo. London: Rift Valley Institute.

UNHCR (2003). Economic and social impact of refugee populations on host developing countries as well as other countries (Standing Committee 26th Meeting (EC/53/SC/CRP.4)). Executive Committee of the High Commissioner's Programme. Retrieved from https://www.unhcr.org/en-Ik/excom/standcom/3e5e31644/economic-social-impact-refugee-populationshost-developing-countries-well.html.

UNHCR (2011). 'Implementation of the comprehensive strategy for the Rwandan refugee situation, including UNHCR's recommendations on the applicability of the 'Ceased Circumstances' Cessation Clauses, 31 December 2011. Retrieved from http://www.unhcr.org/refworld/docid/4f33a1642.html.

UNHCR. (2014). Congolese refugees - A protracted situation (Priority Situation Fact Sheet). UNHCR. Retrieved from http:// www.unhcr.org/558c0e039.pdf.

UNHCR (2018a). Global trends: Forced displacement in 2017. Geneva: UNHCR.

UNHCR. (2018b). Population statistics. Retrieved on 5 September 2018 from http://popstats.unhcr.org/.

Whitaker, E. (1999). Changing opportunities: refugees and host communities in western Tanzania (Working Paper No. 11), (pp. 117). UNHCR. Retrieved from http://www.unhcr.org/3ae6a0c70.pdf.

Whitaker, E. (2002). New issues in refugee research. UNHCR, (pp. 1-17). Washington, DC: United Nations.

World Bank (2013). Lebanon: Economic and social impact assessment of the Syrian conflict (No. 81098-LB). Washington, DC: World Bank. Retrieved from http://documents.worldbank.org/curated/en/925271468089385165/Lebanon-Economic-and social-impact-assessment-of-the-Syrian-conflict.

\section{Publisher's Note}

Springer Nature remains neutral with regard to jurisdictional claims in published maps and institutional affiliations. 